\title{
Efficacy of Pre- and Postinoculation Application of Fungicides to Expanding Young Citrus Leaves for Control of Melanose, Scab, and Alternaria Brown Spot
}

\author{
S. N. Mondal, University of Florida, IFAS, Department of Plant Pathology, Citrus Research and Education Center, \\ Lake Alfred 33850; A. Vicent, Universidad Politécnica de Valencia, Instituto Agroforestal Mediterráneo, Valencia, \\ Spain; R. F. Reis, São Paulo State University, Jaboticabal, São Paulo, Brazil; and L. W. Timmer, University of Flor- \\ ida, IFAS, Department of Plant Pathology, Citrus Research and Education Center
}

\begin{abstract}
Mondal, S. N., Vicent, A., Reis, R. F., and Timmer, L. W. 2007. Efficacy of pre- and postinoculation application of fungicides to expanding young citrus leaves for control of melanose, scab, and Alternaria brown spot. Plant Dis. 91:1600-1606.

In greenhouse trials, copper hydroxide, pyraclostrobin, and famoxadone were applied to actively growing young citrus seedlings to determine the duration of protection of young leaves provided by these fungicides against melanose, caused by Diaporthe citri, citrus scab, caused by Elsinoe fawcettii, and Alternaria brown spot, caused by Alternaria alternata. Fungicides were applied to different sets of potted plants of grapefruit for control of melanose, of rough lemon for control of scab, and of Dancy tangerine for control of Alternaria brown spot 1 to 6 days prior to inoculation, as well as on the day of inoculation. Leaf area of treated shoots was estimated on the day of fungicide application and the day of inoculation and disease severity evaluated subsequently. In most cases, copper hydroxide and famoxadone provided at least 50\% control of all three diseases for only about 2 days after application. Generally, there was little or no disease control when the products were applied 4 or more days before inoculation. In contrast, pyraclostrobin usually provided a high level of control of all three diseases when applied up to 5 days prior to inoculation. The level of disease control decreased as the interval between a fungicide application and inoculation increased and the relationship between disease control and leaf expansion best fit a quadratic equation. Effective disease control was observed with copper hydroxide and famoxadone until leaf area had increased by 100 to $200 \%$, whereas control with pyraclostrobin was observed up to 400 to $500 \%$ increase in leaf area. In postinoculation tests with scab and melanose, pyraclostrobin provided high levels of disease control ( $>75 \%)$ when applied up to 2 days after inoculation, whereas copper hydroxide and famoxadone had minimal postinoculation activity. Applications of pyraclostrobin to the spring flush growth of citrus trees are much more likely to provide control of melanose, scab, and Alternaria brown spot than those of famoxadone or copper hydroxide.
\end{abstract}

Citrus melanose, scab, and Alternaria brown spot are fungal diseases of foliage and fruit that reduce the value of citrus fruit for the fresh market. Melanose is caused by Diaporthe citri F.A. Wolf (anamorph Phomopsis citri H. Fawc. non (Sacc.) Traverso \& Spessa), citrus scab is caused by Elsinoe fawcettii Bitanc. \& Jenkins (anamorph Sphaceloma fawcettii Jenkins), and Alternaria brown spot is caused by Alternaria alternata (Fr.) Keissl. (2528).

Melanose affects all citrus but is most serious on grapefruit and lemon destined for the fresh market. Conidia of $P$. citri are produced on dead twigs in the tree canopy and are rain-splash dispersed to young, susceptible leaves, twigs, and fruit $(20,25,26)$. Fruit are susceptible to infec-

Corresponding author: L. W. Timmer

E-mail: lwtimmer@ufl.edu

Accepted for publication 13 July 2007.

doi:10.1094/PDIS-91-12-1600

(C) 2007 The American Phytopathological Society tion from petal fall until late June or early July in Florida. Leaves are susceptible until they are fully expanded. Infected young leaves are not a source of inoculum for fruit, but infected twigs eventually will produce inoculum and severe infection can cause defoliation.

Citrus scab affects grapefruit, lemon, tangerine, and their hybrids. This disease causes external blemishes that reduce the value of the crop for the fresh market. Conidia of $S$. fawcettii are produced on infected leaves, twigs, and fruit and are dispersed by rain splash. Juvenile tissues are most susceptible. Leaves are susceptible until they are half-expanded and fruit until about 6 to 8 weeks after petal fall $(25,27)$. Infected young leaves are an important source of inoculum for infection of young fruit.

Alternaria brown spot affects mostly tangerine and its hybrids. This disease can cause fruit drop and reduce yields, but is primarily a fruit blemish disease. Alternaria brown spot also can produce leaf drop and thus reduce tree vigor $(23,25)$. Conidia are produced mostly on lesions on mature leaves and are airborne $(23,25,28)$.
Control of Alternaria infections on leaf flushes reduces inoculum build-up in the orchard, and it is essential to prevent defoliation as well. Fruit are susceptible from petal fall to midsummer in Florida. Leaves of highly susceptible cultivars can be infected until they are fully expanded, but those of more tolerant cultivars become resistant much earlier (unpublished data).

Extensive field evaluations of fungicides for control of melanose, scab, and Alternaria brown spot have been conducted in Florida. Copper products and the QoI fungicides, azoxystrobin, pyraclostrobin, and trifloxystrobin, have been most effective for the control of melanose $(13,18,19)$ and Alternaria brown spot $(8-10,16,17)$, and currently are recommended in Florida for control of these diseases (24). These fungicides also are effective for control of citrus scab, although copper products are less effective than the QoI fungicides $(2,14,15)$. In addition, benzimidazole fungicides, ferbam, and fenbuconazole have proven effective for control of scab $(2,8,14,15,30)$.

The activity of most of these fungicides against these diseases is probably largely preventive. However, benzimidazoles and, to a lesser extent, QoI fungicides have postinfectional activity against citrus scab, but not against melanose (11). Captafol, benomyl, fenbuconazole, and ferbam have eradicative activity against citrus scab and reduce inoculum $(29,34)$, but copper fungicides have no postinfectional activity and do not reduce inoculum of scab $(11,29)$. Applications of copper fungicides to brown spot lesions on mature leaves greatly reduce sporulation of A alternata and, thus, reduce inoculum production with this disease (23). Copper fungicides are much more persistent and have greater rain-fastness on fruit for control of Alternaria brown spot compared with other fungicides (31). A model has been developed in Florida that predicts the loss of copper residues on fruit due to fruit growth and rainfall (3).

With these three diseases, protection of rapidly expanding spring flush growth from infection is important. For scab and Alternaria brown spot, protection of these leaves would greatly reduce the inoculum available for infection of fruit later in the season. With melanose, infected twigs, but not leaves or fruit, eventually can produce 
inoculum that infects fruit $(20,22)$. Products that induce host resistance were effective for control of these diseases on young shoots but did not provide a high level of control (1). Currently, fungicide applications to the spring flush of growth are recommended for control of scab and Alternaria brown spot, but not for melanose (24). However, the degree of effectiveness and the duration of protection on rapidly expanding young leaves have never been investigated.

In this study, we evaluated the duration of effectiveness of copper hydroxide, pyraclostrobin, and famoxadone applied before and after inoculation with the respective pathogens in the greenhouse to assess the utility of these products in controlling melanose, scab, and Alternaria brown spot on new shoots and leaves.

\section{MATERIALS AND METHODS}

Plant materials and leaf area measurements. Citrus species that are highly susceptible to each of the diseases were selected for these studies: grapefruit (Citrus paradisi Macfad.) for melanose, rough lemon ( $C$. jambhiri Lush.) for scab, and Dancy tangerine (C. reticulata Blanco) for Alternaria brown spot. Seedlings of these species were grown in 2.7-liter containers in the greenhouse to about $0.5 \mathrm{~m}$ in height. Prior to use, seedlings were pruned to induce a uniform flush of growth.

For experiments to evaluate the effects of preinoculation sprays, three replicate plants with shoots about 10 to $20 \%$ of their final length were selected for each treatment. Three to four shoots on each plant were tagged and three to four leaves on each shoot with about 1 to $3 \mathrm{~cm}^{2}$ in surface area each were marked with a thread. Leaf area was estimated at the time of fungicide application and at the time of inoculation by measuring the length and width of each leaf. Leaves were assumed to be elliptical in shape and the area was calculated by the formula:

$$
\text { Area }=\pi \times \frac{\text { length }}{2} \times \frac{\text { width }}{2}
$$

Nearly all of the leaves were young enough to be infected at the time of inoculation, except possibly a few of the rough lemon leaves inoculated with $E$. fawcettii 4 to 5 days after fungicide application.

Fungicides. Pyraclostrobin was applied as Headline (BASF Corporation) at $0.25 \mathrm{~g}$ a.i./liter, copper hydroxide was applied as Kocide 2000 (Griffin LLC) at $1.4 \mathrm{~g}$ of metallic copper per liter, and famoxadone was applied as DPX-JE874-389 (50\% WG) (E.I. du Pont de Nemours and Company) at $0.1 \mathrm{~g}$ a.i./liter. All fungicide sprays were applied to run-off using a hand-pump sprayer.

Inoculum production and inoculation of plants. Conidia of D. citri were produced using the method of Mondal et al. $(20,22)$. Briefly, autoclaved grapefruit twigs about 2 to $4 \mathrm{~mm}$ in diameter were inoculated with mixtures of isolates Ser-22, P-94, D-1, and JMP-2, and incubated for about 45 days at $25^{\circ} \mathrm{C}$ in the laboratory, during which time the twigs were soaked in tap water three times per week. Spore tendrils oozing from pycnidia were collected using the spore collection tower described previously (20). Conidial concentration was adjusted to $10 \% \mathrm{ml}$ and orange juice was added to a final concentration of $1 \%$ as recommended by Whiteside (33).

Conidia of E. fawcettii isolates Scott, CC-3, Eus Mur-4, and R-36 were produced according to the method of Whiteside (32). Briefly, three to four mycelial pieces, 1 to $2 \mathrm{~mm}^{3}$ in size, were crushed in a sterile petri dish and dispersed in 15 to $20 \mathrm{ml}$ of Fries medium ( $5.0 \mathrm{~g}$ of ammonium tartrate, $1.0 \mathrm{~g}$ of $\mathrm{NH}_{4} \mathrm{NO}_{3}, 1.0 \mathrm{~g}$ of $\mathrm{K}_{2} \mathrm{HPO}_{4}, 0.5 \mathrm{~g}$ of $\mathrm{MgSO}_{4} \cdot 7 \mathrm{H}_{2} \mathrm{O}, 0.1 \mathrm{~g}$ of $\mathrm{CaCl}_{2}, 0.1 \mathrm{~g}$ of $\mathrm{NaCl}$, and $20 \mathrm{~g}$ of sucrose per liter of distilled water) and incubated at $25^{\circ} \mathrm{C}$ for 2 days. Microcolonies attached to the bottom of the plate were washed three times with sterile, distilled water, flooded with sterile lake water, and incubated at $25^{\circ} \mathrm{C}$ overnight in the dark. Conidial concentration of a mixture of the isolates was adjusted to $10^{6} / \mathrm{ml}$.

Conidia of A. alternata isolates EV-315 and SH-368 were produced by first growing cultures on potato dextrose agar (PDA) for 2 weeks at $25^{\circ} \mathrm{C}$ in the dark. Dishes were flooded with sterile distilled water and then scraped to produce a suspension of mycelial fragments. New PDA dishes then were seeded with the mycelial fragment suspension and incubated for 3 to 4 days at $25^{\circ} \mathrm{C}$ with $12 \mathrm{~h}$ of fluorescent light daily. Plates were flooded with sterile distilled water with $0.1 \%$ Tween 20 and scraped gently with a spatula to dislodge conidia. Conidial suspensions were filtered through two layers of cheesecloth to remove mycelial fragments, and the conidial concentration of the isolate mixture was adjusted to $10^{5} / \mathrm{ml}$.

In all cases, plants were inoculated with a mixture of isolates to assure high levels of infection. Inoculations were conducted by spraying plants to run-off with conidial suspensions using a chromatography sprayer (Crown Sprā-Tool, North American Professional Products, Woodstock, IL). Then, plants were covered with plastic bags for 16 to $24 \mathrm{~h}$ in an incubator at $27^{\circ} \mathrm{C}$ and subsequently transferred to the greenhouse for symptom development.

Postinoculation evaluations were conducted similarly except that applications were made 1 to 4 days after inoculation. No postinoculation experiments were conducted with Alternaria brown spot because symptoms of that disease often appear in 1 to 2 days. Leaf areas were not calculated in these studies.

Experimental design and disease evaluations. For each disease, one group of three replicate plants was sprayed with fungicide 4 to 6 days prior to inoculation, depending on the experiment, and another group of three plants was sprayed each day until the day of inoculation. As a control, three nonsprayed plants were inoculated on each day and disease severity rated after incubation. As a standard, a group of plants was sprayed on the day of inoculation and the spray was allowed to dry prior to inoculation. All experiments on preinoculation effectiveness were repeated once or twice, and two experiments were conducted on each postinoculation test.

Disease severity of each leaf was rated on a 0 -to-5 scale 7 to 10 days after inoculation for melanose and scab and 3 to 5 days after inoculation for Alternaria brown spot. For melanose, disease severity was rated on a scale of: $0=$ no lesions, $1=1$ to 10 lesions, $2=11$ to 50 lesions, $3=51$ to 100 lesions, $4=101$ to 200 lesions, and 5 $=$ confluent lesions. For scab, the scale was $0=$ no lesions, $1=1$ to 3 lesions, $2=4$ to 10 lesions, $3=11$ to 20 lesions, $4=20$ to 50 lesions, and $5=>50$ lesions. For Alternaria brown spot, the scale was $0=$ no lesions, $1=1$ to 2 lesions, $2=3$ to 5 lesions, $3=6$ to 10 lesions, $4=11$ to 15 lesions, and $5=>15$ lesions.

Data analysis. The mean disease severity was calculated for each application time for the treated plants and the controls. Data were expressed as the percent disease control based on the nonsprayed control. Standard errors of the means were calculated.

Because some variability was observed in the rate of leaf expansion and disease response in the preinoculation experiments, likely due to differences in temperature and day length, all experiments are presented separately. Variances were equal in these postinoculation experiments as determined by Bartlett's test; therefore, the data were pooled for presentation.

Data from all experiments on preinoculation sprays were used to evaluate the effect of percent increase in leaf area on the percent control on each disease. Data for each fungicide were fit to a quadratic equation to compare the activity of the different products using SigmaPlot (version 10; Systat Software Inc., San Jose, CA). In these analyses, the percent disease control was calculated based on the percent disease control when fungicides were applied on the day of inoculation as $100 \%$ so that all fungicides were comparable at the outset.

\section{RESULTS}

Preinoculation applications. Melanose. With melanose, pyraclostrobin and copper hydroxide were compared in experiment $\mathrm{A}$ and, when applied just prior to inoculation, both fungicides provided nearly $100 \%$ disease control (Fig. 1A). Disease control with copper hydroxide declined rapidly with increasing interval between applica- 
tion and inoculation, but activity of pyraclostrobin was still high after 4 days. In experiment $\mathrm{B}$, disease control with pyraclostrobin, famoxadone, or copper hydroxide ranged from 65 to $100 \%$ when plants were inoculated the day they were sprayed (Fig. 1B). Pyraclostrobin provided 100\% control when applied 4 days before inocu- lation; however, neither copper hydroxide nor famoxadone greatly reduced disease severity with this timing. Similar results were observed in experiment $\mathrm{C}$ (Fig. 1C); however, in this experiment, percent disease control with pyraclostrobin was less than $60 \%$ when applied 5 or 6 days before inoculation.
Scab. With this disease, control was 75 to $100 \%$ when fungicides were applied just prior to inoculation (Fig. 2). In all experiments, disease control with copper hydroxide or famoxadone declined rapidly with increasing time between the spray and inoculation, but disease control with pyraclostrobin was still high after 4 to 5 days.

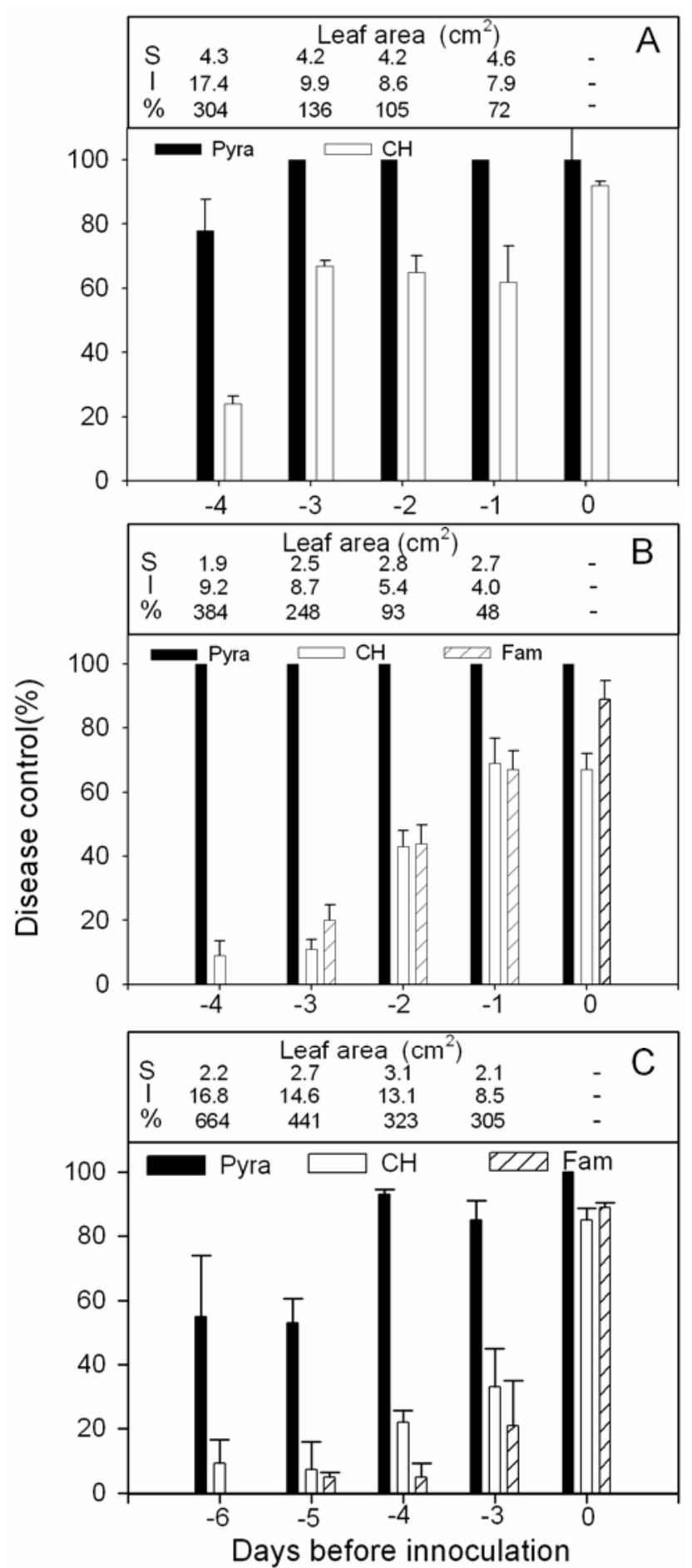

Fig. 1. Effect of pyraclostrobin, copper hydroxide, and famoxadone on control of melanose in applications to expanding young leaves of grapefruit seedlings 0 to 6 days before inoculation. $\mathbf{A}, \mathbf{B}$, and $\mathbf{C}$ represent different experiments. Vertical bars represent the standard error of the mean of the percent disease control. For each group of plants, the average leaf area on the date sprayed (S) and on the date inoculated (I), and the percent increase in leaf area $(\%)$ between those two dates, are presented above.

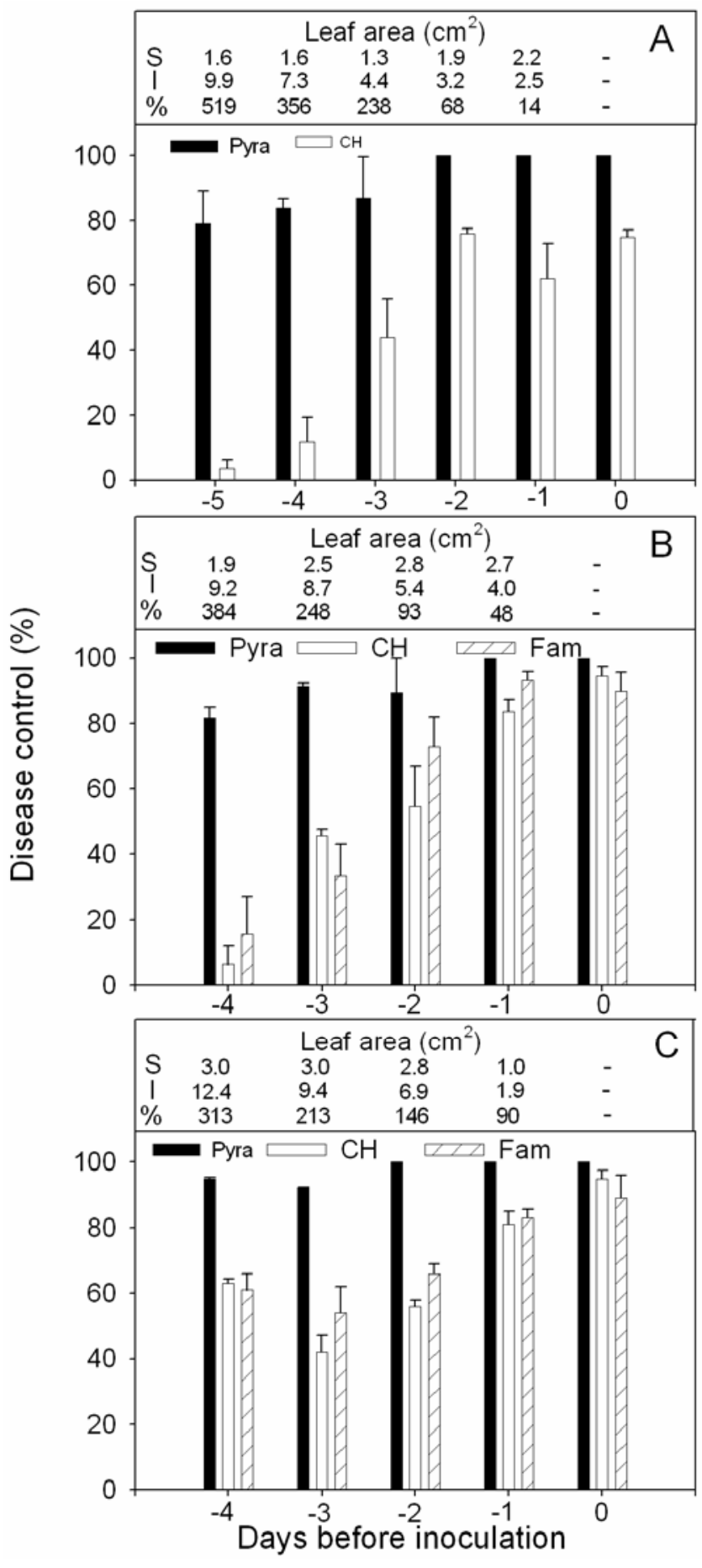

Fig. 2. Effect of pyraclostrobin, copper hydroxide, and famoxadone on control of citrus scab in applications to expanding young leaves of rough lemon seedlings 0 to 6 days before inoculation. $\mathbf{A}, \mathbf{B}$, and $\mathbf{C}$ represent different experiments. Vertical bars represent the standard error of the mean of the percent disease control. For each group of plants, the average leaf area on the date sprayed (S) and on the date inoculated (I), and the percent increase in leaf area $(\%)$ between those two dates, are presented above. 
In experiment $\mathrm{C}$ (Fig. 2C), the activities of famoxadone and copper hydroxide declined less with increasing time between application and inoculation, but the activities of these products were still much less than pyraclostrobin.

Alternaria brown spot. Trends similar to those for melanose and scab were observed with Alternaria brown spot (Fig. 3). However, in experiment A, the activity of copper hydroxide did not decline greatly with increasing time between application and inoculation. In this experiment, leaf area increased by only $182 \%$ from the time of application to 6 days later, when leaves were inoculated (Fig. 3A). In experiment B (Fig. 3B), pyraclostrobin applied up to 4 days before inoculation persisted better than famoxadone or copper hydroxide; however, at the 6-day interval, none of the fungicides provided a high level of control.

Relationship of fungicide activity to leaf expansion. Percent disease control declined significantly with increase in leaf area with all three diseases and all fungicides tested (Fig. 4). However, this decline in activity was much slower with pyraclostrobin than with copper hydroxide or famoxadone. The activity of pyraclostrobin was more persistent against scab than against melanose or Alternaria brown spot. Once leaf area had doubled, disease control with copper hydroxide was seldom greater than $60 \%$. In contrast, with pyraclostrobin, disease control was seldom less than $60 \%$ even when leaf area had increased by 300 to $400 \%$.

Postinoculation control. When fungicides were applied after inoculation, pyraclostrobin provided significant control of scab and melanose for at least 2 days and still had some effect even after 3 to 4 days (Fig. 5). In contrast, some disease control was observed when famoxadone and copper hydroxide were applied 1 day after inoculation, but little disease control was observed if applied later. There were no significant differences between the performance of copper hydroxide and famoxadone with either disease.

\section{DISCUSSION}

Despite the importance of preventing infection of spring flush growth from foliar fungal pathogens of citrus, the fungicides evaluated in this study were effective for only a short time after application. With relatively cool conditions during the spring in Florida, this flush of growth requires about 3 weeks from new leaf emergence to full expansion. Growers generally only have sufficient numbers of sprayers to make about one application every 3 weeks. Considering the results of this study, copper fungicides or famoxadone would probably require two applications per week and pyraclostrobin would require weekly sprays for full protection of foliage. Frequent applications would not be economically feasible and also could select strains of the pathogen with fungicide resistance unless fungicides were rotated.

Another approach to controlling diseases on growing leaves is to apply compounds that induce systemic disease resistance just prior to or at the beginning of spring flush growth. The level of control attained is not high with these materials, but the activity is more persistent (1). We have achieved some success using this approach with Alternaria brown spot $(7,12)$ and scab (2). Applications of such products to the spring flush for these diseases have provided control equal to that achieved with standard fungicides in the field in some cases. These products can be applied at a very early stage of shoot development and provide at least some protection until the shoots mature.

With melanose, the value of protecting the spring flush growth is probably less than with the other diseases because no inoculum is produced on new shoots and leaves affected by melanose until they die. Such applications would prevent infection of twigs and potentially reduce inoculum production after twig death. However, $D$. citri is able to colonize dead twigs saprophytically (22); thus, protecting new shoots may have limited benefit for reducing overall inoculum production.

Protecting spring flush growth from scab is very important. Normally, three applications are recommended for scab control: one to protect spring flush growth, one after petal fall to protect new fruit, and a third about 3 weeks later to protect fruit until it becomes resistant about 6 weeks after petal fall (24). Spray programs in which an ineffective product is used in the spring flush spray make it much more difficult to control the disease subsequently on the young fruit (2). Even though copper fungicides are active against

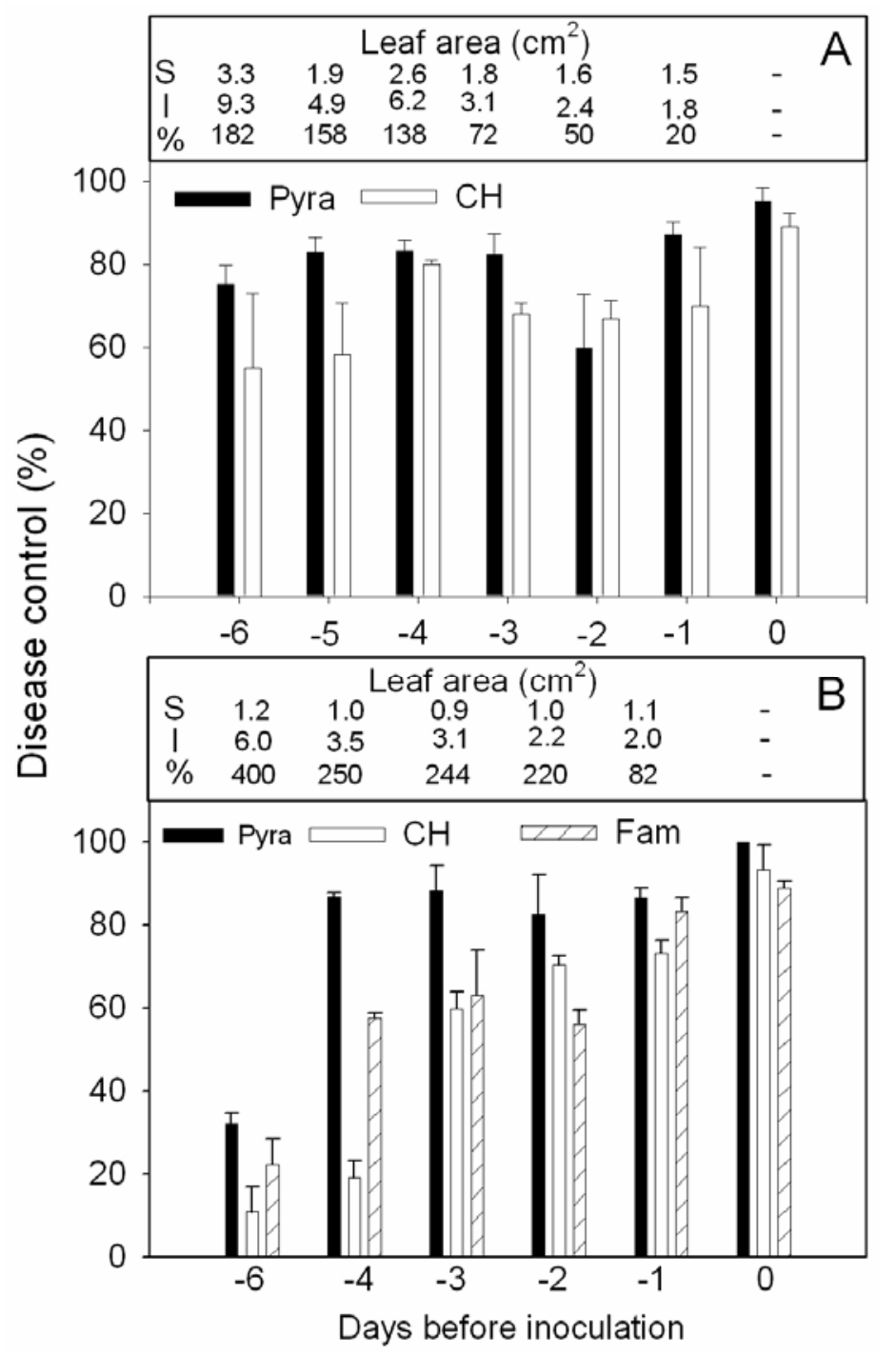

Fig. 3. Effect of pyraclostrobin, copper hydroxide, and famoxadone on control of Alternaria brown spot in applications to expanding young leaves of Dancy tangerine seedlings from 0 to 6 days before inoculation. A and $\mathbf{B}$ represent different experiments. On graphs, bars represent the standard error of the mean of the percent disease control. For each group of plants, the leaf average area on the date sprayed (S) and on the date inoculated (I), and the percent increase in leaf area (\%) between those two dates, are presented above. 


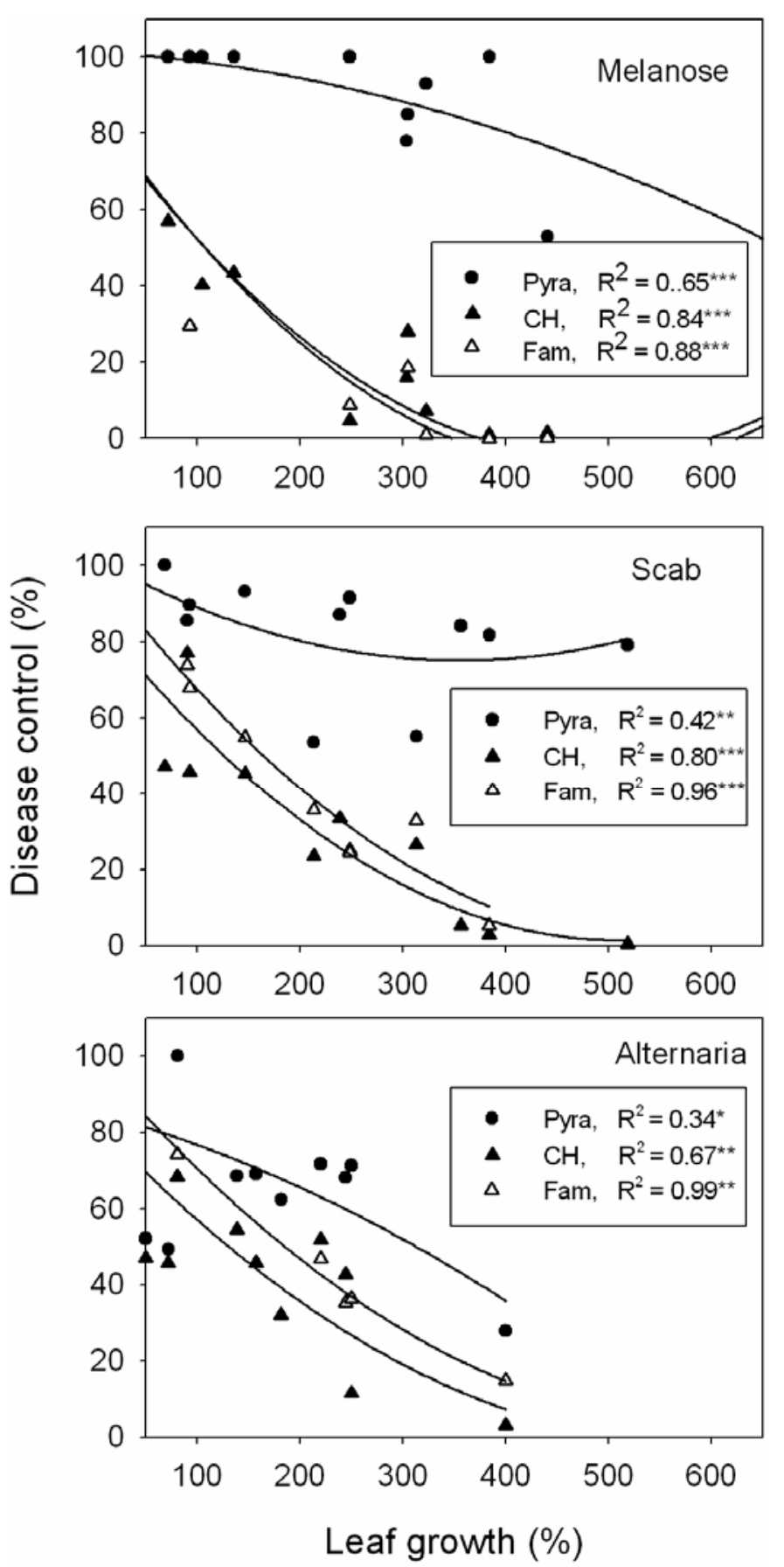

Fig. 4. Relationship of leaf expansion to the percentage of disease control of melanose, scab, and Alternaria brown spot. For melanose, the equations are $y=101.4-0.01 x-0.0001 x^{2}$ for pyraclostrobin, $y$ $=85.6-0.37 x+0.0004 x^{2}$ for copper hydroxide, and $y=87.5-0.39 x+0.0004 x^{2}$ for famoxadone. For scab, the equations are $y=102.03-0.15 x+0.0002 x^{2}$ for pyraclostrobin, $y=87.26-0.33 x+0.0003 x^{2}$ for copper hydroxide, and $y=100.07-0.35 x+0.0003 x^{2}$ for famoxadone. For Alternaria brown spot, the equations are $y=85.37+0.3 x+0.0001 x^{2}$ for pyraclostrobin, $y=83.3-0.28 x+0.002 x^{2}$ for copper hydroxide, and $y=99.38-0.31 x+0.0003 x^{2}$ for famoxadone.

the pathogen, control in the field is often poor. In two tests, three applications of Kocide 2000 failed to increase the percentage of marketable fruit significantly $(2,15)$. In another test, three applications of Kocide 2000 were much less effective than three of ferbam, but a treatment with azoxystrobin followed by ferbam and then Kocide 2000 was highly effective (14). Based on those results, we have concluded that copper fungicides are effective for scab control only when applied in the final spray to protect fruit that is larger and expanding more slowly; thus, copper fungicides are recommended only for the last application of the season (24). Those results of field tests are understandable now because copper fungicides were effective for a much shorter period on young leaves than pyraclostrobin in the current study. Timing of applications for scab control is difficult because leaves become resistant to infection when half expanded. If fungicides are applied early when the leaves are small and protection is most needed, fungicide activity is lost due to rapid leaf expansion. If application is delayed until leaves are larger, there is a risk of infection prior to application. Because pyraclostrobin and other QoI fungicides have postinfectional and eradicant activity, they can be applied when leaves are small and still provide good control $(6,11)$. Even normally protectant products such as ferbam and fenbuconazole have eradicant activity (30) because some mycelium and the conidiophores are exposed on the surface of the pustules and inoculum production is reduced following application. Thus, it is probably best to delay fungicide applications somewhat and risk some early infection. If QoI fungicides are used, the postinfectional and eradicant activity of these products would prevent inoculum production on leaves and help protect fruit.

For Alternaria brown spot, protection of the spring flush of growth would appear to be important to prevent defoliation and reduce inoculum production on leaves after they mature $(23,25)$. Based on the results of the current study, pyraclostrobin would provide longer protection than copper fungicides. This protection probably would last longer if sprays were delayed until leaves were larger and expanding more slowly, but then there is a risk of infection prior to application. Leaves of at least some citrus cultivars are still susceptible to infection by A. alternata even when fully expanded, as long as they are still tender, whereas other cultivars develop resistance before they are completely expanded (unpublished data). Thus, in contrast to scab, protection is needed late in flush expansion with the most susceptible cultivars.

In this study, we chose to make the first fungicide applications when leaves were relatively small ( 1 to $3 \mathrm{~cm}^{2}$ in area) in order to determine the effects of leaf expansion on disease control. Copper fungicides are strictly protectant materials and, although highly persistent, are not redistributed and are not expected to provide long residual control when applied to expanding leaves. In contrast, famoxadone has good residual activity and is redistributed by diffusion in cuticular waxes and by dissolution in water and redeposition $(4,5)$. Famoxadone was expected to provide better control than copper under those circumstances. However, in our studies, it provided residual control longer than copper only in rare cases, suggesting that it may lack the ability to redistribute in citrus leaves. Pyraclostrobin is taken up into plant leaves to only a limited extent and has limited translaminar movement (6). In this study, pyraclostrobin substantially outperformed copper and famoxadone in providing residual control of the three diseases of citrus investigated. Pyraclostrobin is highly stable in plant leaves (6) 


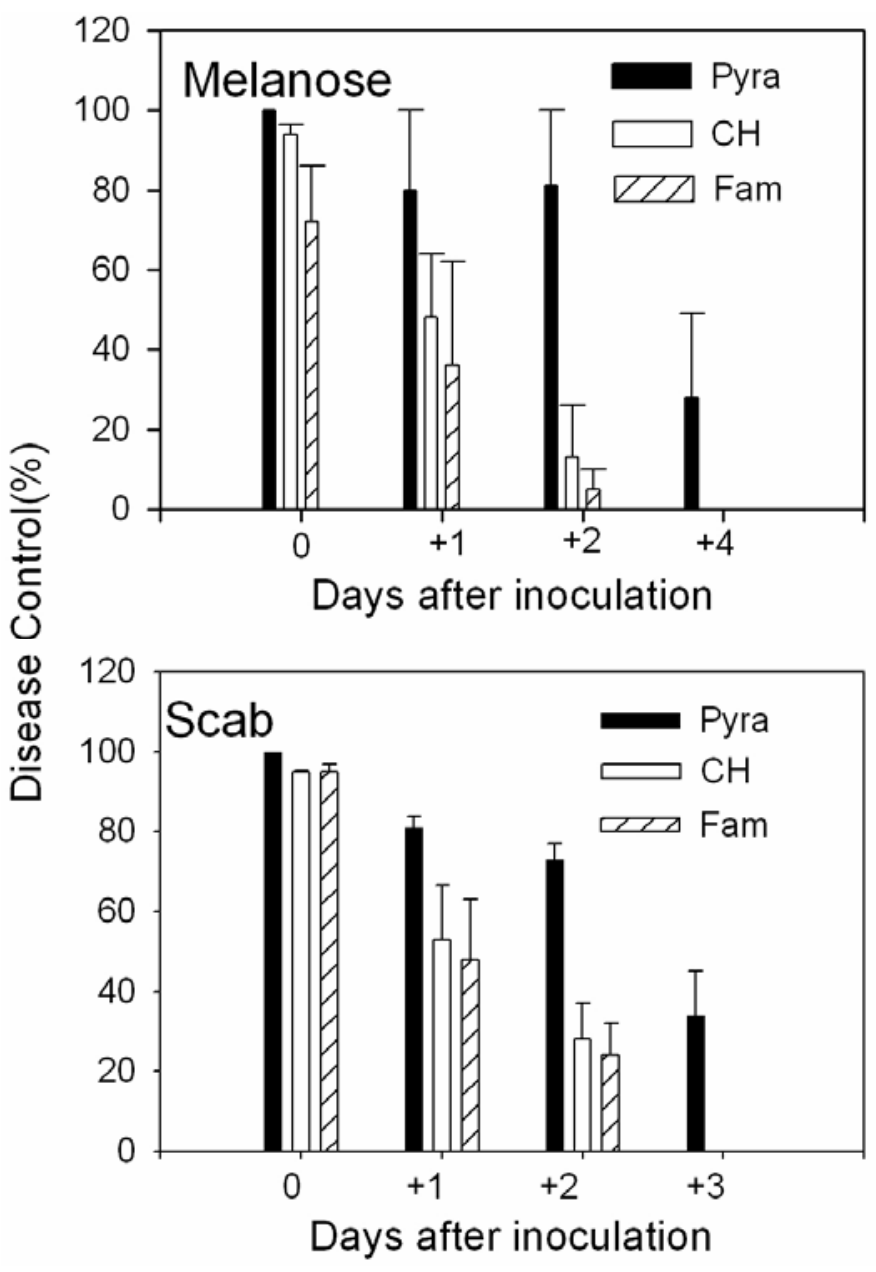

Fig. 5. Percent disease control of melanose and scab when pyraclostrobin, copper hydroxide, and famoxadone were applied 0 to 4 days after inoculation of grapefruit or rough lemon seedlings, respectively.

and highly toxic to these fungi (21). Thus, this fungicide may have been taken up into plant cells and have been redistributed through the leaf with cell division. Pyraclostrobin is highly active against these pathogens of citrus (21) and relatively low amounts of the compound would be needed to provide control. In our experiments, leaves were sprayed to run-off with uniform coverage. Under field conditions, coverage may be less optimal; therefore, the high level of activity and its ability to redistribute gives pyraclostrobin many advantages over protectants. These tests were conducted in the greenhouse and results in the field might differ somewhat. Under field conditions, young leaves might grow more slowly if temperatures were cooler than those in the current tests. Because all of our data are expressed as percent increase in leaf surface area, duration of effectiveness can be estimated easily. The other differences in the field would be that the occurrence of rainfall could shorten the duration of effectiveness even more and that there is considerable variability in time of emergence of new shoots. Thus, we expect that results in the field would be very similar to those obtained in our greenhouse study.

\section{LITERATURE CITED}

1. Agostini, J. P., Bushong, P. M., and Timmer, L. W. 2003. Greenhouse evaluation of products that induce host resistance for control of scab, melanose, and Alternaria brown spot of citrus. Plant Dis. 87:69-74.

2. Agostini, J. P., Tesoriero, A. J., and Timmer, L. W. 2002. Evaluation of products for the control of citrus scab on Temple tangors, 2001. Fungic. Nematicide Tests (online) Rep. 57:M10. DOI.10.1094/FN57. The American Phytopathological Society, St. Paul, MN.

3. Albrigo, L. G., Beck, H. W., Timmer, L. W., and Stover, E. 2005. Development and testing of a recommendation system to schedule copper sprays for citrus disease control. J. ASTM Int. 9(2):1-12. Online: DOI: 10.1520/JAI 12904.

4. Andrieu, N., Gene, J.-L., Jaworska, G., and Bompeix, G. 2000. Behaviour of famoxadone deposits on grape leaves. Pest Manage. Sci. 56:1036-1042.

5. Andrieu, N., Jaworska, G., Genet, J.-L., and Bompeix, G. 2001. Biological mode of action of famoxadone on Plasmopara viticola and Phytophthora infestans. Crop Prot. 20:253260.

6. Bartlett, D. W., Clough, J. M., Godwin, J. R., Hall, A. A., Harner, M., and Parr-Dobrzanksi, B. 2002. The strobilurin fungicides. Pest Manage. Sci. 58:649-662.

7. Bhatia, A., Tesoriero, A. J., and Timmer, L. W. 2002. Evaluation of fungicides for control of Alternaria brown spot on Murcotts, 2001. Fungic. Nematicide Tests (online) Rep. 57:M06. DOI.10.1094/FN57. The American Phytopa- thological Society, St. Paul, MN.

8. Bhatia, A., and Timmer, L. W. 2003. Evaluation of products for control of citrus scab on Temple tangor, 2002. Fungic. Nematicide Tests (online) Rep. 58:MO04.DOI.10.1094/FN58. The American Phytopathological Society, St. Paul, MN.

9. Bhatia, A., and Timmer, L. W. 2003. Evaluation of the Alter-Rater model for timing of fungicide applications for control of Alternaria brown spot of citrus. Plant Dis. 87:1089-1093.

10. Bhatia, A., and Timmer, L. W. 2004. Evaluation of products for control of Alternaria brown spot on Murcott tangors, 2002. Fungic. Nematicide Tests (online) Rep. 59:V031.M06. DOI.10.1094/FN59. The American Phytopathological Society, St. Paul, MN.

11. Bushong, P. M., and Timmer, L. W. 2000 Evaluation of postinfection control of citrus scab and melanose with benomyl, fenbuconazole, and azoxystrobin. Plant Dis. 84:12461249 .

12. Johnston, T., Marais, L., and Timmer, L. W. 2004. Alternatives against Alternaria brown spot: controlling brown spot on Murcott tangors. Pages 379-381 in: Proc. 20th Annu. Alltech Symp. T. P. Lyons and K. A. Jacques, eds. Nottingham University Press, Nottingham, UK.

13. Johnston, T., and Timmer, L. W. 2004. Evaluation of products for control of melanose on grapefruit, 2002. Fungic. Nematicide Tests (online) Rep. 59:V026.DOI.10.1094/FN59. The American Phytopathological Society, St. Paul, MN.

14. Johnston, T., and Timmer, L. W. 2004. Evaluation of products for control of citrus scab on Marsh grapefruit, 2003. Fungic. Nematicide Tests (online) Rep. 59:V028.DOI.10.1094/ FN59. The American Phytopathological Society, St. Paul, MN.

15. Johnston, T., and Timmer, L. W. 2005. Evaluation of products for control of citrus scab on Marsh grapefruit, 2004. Fungic. Nematicide Tests (online) Rep. 60:V026.M06.DOI.10. 1094/FN60. The American Phytopathological Society, St. Paul, MN.

16. Johnston, T., and Timmer, L. W. 2005. Evaluation of fungicides for control of Alternaria brown spot on Nova tangelo, 2004. Fungic. Nematicide Tests (online) Rep. 60:V027.M06 DOI.10.1094/FN60. The American Phytopathological Society, St. Paul, MN.

17. Johnston, T., and Timmer, L. W. 2005. Evaluation of fungicides for control of Alternaria brown spot on Minneola tangelo, 2004. Fungic. Nematicide Tests (online) Rep. 60:V028. M06.DOI.10.1094/FN60. The American Phytopathological Society, St. Paul, MN.

18. Johnston, T., and Timmer, L. W. 2005. Evaluation of products for control of melanose on grapefruit, 2004. Fungic. Nematicide Tests (online) Rep. 60:V148.M06.DOI.10.1094/ FN60. The American Phytopathological Society, St. Paul, MN.

19. Johnston, T., and Timmer, L. W. 2005. Evaluation of products for control of melanose on Duncan grapefruit, 2003. Fungic. Nematicide Tests (online) Rep. 60:V149.M06.DOI. 10.1094/FN60. The American Phytopathological Society, St. Paul, MN.

20. Mondal, S. N., Agostini, J. P., Zhang, L., and Timmer, L. W. 2004. Factors affecting pycnidium production of Diaporthe citri on detached citrus twigs. Plant Dis. 88:379-382.

21. Mondal, S. N., Bhatia, A., Shilts, T., and Timmer, L. W. 2005. Baseline sensitivities of fungal pathogens of fruit and foliage of citrus to azoxystrobin, pyraclostrobin, and fenbuconazole. Plant Dis. 89:1186-1194.

22. Mondal, S. N., Vicent, A., Reis, R. F., and Timmer, L. W. 2006. Saprophytic colonization of citrus twigs and factors affecting survival of conidia of Diaporthe citri, the cause of 
melanose. Plant Dis. 91:387-392.

23. Reis, R.F., Mondal, S. N., Shilts, T., Brentu, F. C., and Timmer, L. W. 2006. Effect of lesion age, humidity, and fungicide application on sporulation of Alternaria alternata, the cause of brown spot of tangerine. Plant Dis. 90:10511054.

24. Rogers, M. E., and Timmer, L. W., eds. 2006. 2006 Florida Citrus Pest Management Guide. Univ. Fla. Inst. Food Agric. Sci. Publ. No. SP43.

25. Timmer, L. W. 1999. Diseases of fruit and foliage. Pages 107-115 in: Citrus Health Management. L. W. Timmer and L. W. Duncan, eds. American Phytopathological Society Press, Inc., St. Paul, MN.

26. Timmer, L. W. 2000. Melanose. Pages 28-29 in: Compendium of Citrus Diseases, 2 nd ed. L. W. Timmer, S. M. Garnsey, and J. H. Graham, eds. American Phytopathological Society, St. Paul, MN.

27. Timmer, L. W. 2000. Scab diseases. Pages 3132 in: Compendium of Citrus Diseases, 2nd ed. L. W. Timmer, S. M. Garnsey, and J. H. Graham, eds. American Phytopathological Society, St. Paul, MN.

28. Timmer, L. W., Solel, Z., and Orozco-Santos, M. 2000. Alternaria diseases. Page 19 in: Compendium of Citrus Diseases, 2nd ed. L. W. Timmer, S. M. Garnsey, and J. H. Graham, eds. American Phytopathological Society, St. Paul, MN.

29. Timmer, L. W., and Zitko, S. E. 1993. Techniques for greenhouse evaluation of fungicides for control of citrus scab. Pages 125-129 in: Proc. IV Congr. Int. Soc. Citrus Nurserymen. E. Rabe, ed. The South African Citrus Nurserymen's Association.
30. Timmer, L. W., and Zitko, S. E. 1997. Evaluation of fungicides for control of Alternaria brown spot and citrus scab. Proc. Fla. State Hortic. Soc. 110:71-76

31. Vicent, A., Armengol, J., and García-Jiménez, J. 2007. Rain fastness and persistence of fungicides for control of Alternaria brown spot of citrus. Plant Dis. 91:393-399.

32. Whiteside, J. O. 1975. Biological characteristics of Elsinoe fawcettii pertaining to the epidemiology of sour orange scab. Phytopathology 65:1170-1175.

33. Whiteside, J. O. 1977. Sites of action of fungicides in the control of citrus melanose. Phytopathology 67:1067-1072.

34. Whiteside, J. O. 1979. Citrus scab control with benomyl in relation to time of spraying and sites of fungicide deposition. Plant Dis. Rep. 63:553-557. 